\title{
Vascular Endothelial Growth Factor Expression in Low and High Grade B-cell Non-Hodgkin's Lymphomas
}

\section{Düşük ve Yüksek Dereceli B-Hücreli Non-Hodgkin Lenfomalarda Vasküler Endotelyal Büyüme Faktörü Ekspresyonu}

\author{
İrem Hicran ÖZBUDAK, Bahar AKKAYA, Gülten KARPUZOĞLU
}

Department of Pathology, Akdeniz University, Faculty of Medicine, ANTALYA, TURKEY

\begin{abstract}
Objective: Angiogenesis is critical for the development of tumors. Although vascular endothelial growth factor is a well-known proangiogenic factor, its impact on B-cell non-Hodgkin's lymphoma is not clear. The aim of this study is to evaluate vascular endothelial growth factor expression in subtypes of B-cell non-Hodgkin's lymphoma .

Material and Method: Fifty-one patients with diagnoses of low and high grade B-cell non-Hodgkin's lymphoma were randomly selected and proper slides were immunostained with vascular endothelial growth factor antibody. The percentage of positive cells was recorded as the vascular endothelial growth factor score. A cut-off point was determined by using the median vascular endothelial growth factor score of all cases. The patients were subclassified as negative, weak or strong positive according to this cut-off point.
\end{abstract}

Results: The study cohort included 26 women and 25 men, aged 5 to 82 years. The number of low-grade patients diagnosed as grade I follicular lymphoma and small lymphocytic lymphoma were 7 and 6; while the number of high grade patients diagnosed as diffuse large B-cell lymphoma and Burkitt's lymphoma were 29 and 9, respectively. Twenty-five patients $(49.0 \%)$ showed strong and 10 patients $(19.6 \%)$ showed weak vascular endothelial growth factor immunoreactivity, while 16 patients (31.4\%) showed no staining. No statistically significant difference was found for vascular endothelial growth factor expression between subtypes of B-cell non-Hodgkin's lymphoma; as well as between low and high grade groups.

Conclusion: Further studies in large and specific series are needed to determine the role of vascular endothelial growth factor receptor related pathways in the development and progression of B-cell non-Hodgkin's lymphomas.

Key Words: Vascular endothelial growth factor, B-cell non-Hodgkin's lymphoma
ÖZ

Amaç: Anjiogenez tümör gelişimi için önemlidir. İyi bilinen bir proanjiogenik faktör olan vasküler endotelyal büyüme faktörünün B-hücreli non-Hodgkin lenfomalardaki etkisi açı değildir. Bu çalışmanın amacı, B-hücreli non-Hodgkin lenfomalardaki alt gruplarında vasküler endotelyal büyüme faktörü ekspresyonunu değerlendirmektir.

Gereç ve Yöntem: Çalışmaya düşük ve yüksek dereceli B-hücreli non-Hodgkin lenfomalarda tanısı almış 51 olgu alınmış ve bu olgularda vasküler endotelyal büyüme faktörü immünhistokimya ile değerlendirilmiştir. Pozitif hücre yüzdesi, vasküler endotelyal büyüme faktörü skoru olarak kaydedilmiştir. Hastaların genelinin ortanca değeri eşik değer kabul edilmiştir. Bu değere göre hastalar negatif, zayıf ya da güçlü pozitif olarak sınıflandırılmıştır.

Bulgular: Çalışma grubu yaşları 5-82 arasında değişen 26 kadın ve 25 erkekten oluşmaktadır. Derece I foliküler lenfoma ve küçük lenfositik lenfoma tanısı alan hastaların sayısı sırasıyla 7 ve 6 ; diffüz büyük B hücreli lenfoma ve Burkitt lenfoma tanısı alan hastaların sayısı ise sırasılyla 29 ve 9'dur. Yirmi beş hastada (\% 49,0) güçlü pozitiflik ve 10 hastada $(\% 19,6)$ zayif pozitiflik izlenirken, 16 hastada (\% 31,4) hiçbir boyanma görülmemiştir. Vasküler endotelyal büyüme faktörü expresyonu açısından B-hücreli non-Hodgkin lenfoma’ların alt grupları yanısıra düşük ve yüksek dereceli gruplar arasında istatistiksel olarak anlamlı fark bulunmamıştır.

Sonuç: Lenfomaların ortaya çıkmasında ve ilerlemesinde vasküler endotelyal büyüme faktörü reseptör ilişkili yolakların rolünü belirlemek adına daha büyük ve spesifik serilerde çalışmalara ihtiyaç vardır.

Anahtar Sözcükler: Vasküler endotelyal büyüme faktörü, B-hücreli non-Hodgkin lenfoma

Correspondence: İrem Hicran ÖZBUDAK

Department of Pathology, Akdeniz University, Faculty of Medicine, ANTALYA, TURKEY

E-mail: iremhicrang@hotmail.com Phone: +90 2422496000 


\section{INTRODUCTION}

Tumors require nutrients and oxygen to grow. The formation of new tumor-feeding blood vessels from preexisting vasculature, named angiogenesis, provides these substrates. This is critical for the development of human tumors and also a prerequisite for metastasis (1).

Tumor angiogenesis is influenced by a wide variety of regulatory and growth factors. Proangiogenic factors secreted by tumor cells and/or host factors stimulate endothelial cells to proliferate and to form new blood vessels that are qualitatively poor and often leaky. Vascular endothelial growth factor (VEGF) is the best-characterized proangiogenic factor in physiological and pathological conditions. Its expression is regulated by intrinsic and extrinsic factors, such as hypoxia, growth factors, cytokines, and oncogenes (2).

The importance of angiogenesis and VEGF in solid tumors is well known. It has been shown that VEGF has a prognostic significance in many types of solid tumors. However, its role in hemato-lymphoid malignancies is not well established.

The aim of this study was to evaluate VEGF expression in subtypes of B-cell non-Hodgkin's lymphoma (B-NHL).

\section{MATERIAL and METHOD}

The study included 51 randomly selected patients with B-NHL diagnosed at the Department of Pathology, Akdeniz University Medical School. Tissue samples were fixed in 10\% buffered formalin and embedded in paraffin. The subtypes were classified according to the WHO 2008 classification (3). As these were initial diagnoses, all the study was performed on untreated patients.

Four-micrometer slides were deparaffinized and treated with $0.01 \mathrm{M}$ citrate buffer for antigen retrieval. Endogenous peroxidase was blocked with $3 \%$ hydrogen peroxide for 5 minutes and followed by incubation with phosphatebuffered saline containing 10\% normal goat serum for 10 minutes. The slides were then incubated for 1 hour at room temperature with VEGF antibody (Code M 134, 1:400; Takara, Kyoto, Japan). Immunoreactions were detected by labeled streptavidin-biotin-peroxidase complex technique and visualized with diaminobenzidine substrate for a period of 10 minutes and counterstained with hematoxylin. Placenta was used as positive control and normal immunoglobulin-G was substituted by primary antibody as the negative control.

The degree of VEGF immunoreactivity was considered to be positive if unequivocal staining of the membrane or cytoplasm was seen in more than $10 \%$ of the tumor cells (4). The percentage of positive cells was recorded in a number of fields at a magnification of x200. Depending on the amount of tissue on the slide, the number of fields evaluated ranged from 4 to 6 . The mean value was used as the final VEGF score (VEGF percentage area) for each case. A cut-off point was determined by using the median VEGF score of all cases (5). The patients were subclassified as negative if there was no staining or unequivocal staining of the membrane or cytoplasm was seen in less than $10 \%$ of the tumor cells. According to VEGF cut-off point, the patients were subclassified as weak if the number of stained cells were less than the cut-off value or as strong if stained cells were more than cut-off value.

Statistical analyses were performed using the Statistical Software Package for the Social Sciences, version 13.0 for Windows (SPSS Inc, Chicago, IL). The chi- square test $\left(\mathrm{X}^{2}\right)$ was used to compare categorical variables. A result was considered significant if the $\mathrm{P}$ value was $<0.05$.

\section{RESULTS}

Patients with B-NHL included 26 women and 25 men, aged 5 to 82 years (mean, $50.8 \pm 19.4$ years). The histological types were as follows: follicular lymphoma Grade 1 (FL), 7 patients (13.7\%); small lymphocytic lymphoma (SLL), 6 patients (11.8\%); diffuse large B-cell lymphoma (DLBCL), 29 patients (56.9\%) and Burkitt's lymphoma (BL), 9 patients (17.6\%). For the statistical analyses the patients were grouped as low grade B-NHL including SLL and FL (13 patients $=25.5 \%)$; and as high grade B-NHL including DLBCL and BL (38 patients $=74.5 \%)$.

Most cases expressed VEGF (35, 68.6\%). The cut-off point was found to be $50.0 \%$ which was the median VEGF score of all cases. Accordingly, 25 patients (49.0\%) showed strong VEGF immunoreactivity and the remainder showed either weak $(10$ patients $=19.6 \%)$ or no $(16$ patients $=31.4 \%)$ staining (Figure 1A,B, 2A,B). In low grade B-NHL, 3 patients were negative for VEGF whereas 2 patients were weak and 8 patients were strong positive. In high grade B-NHL, 17 patients were strong, 8 patients were weak positive and 13 patients were negative for VEGF (Table I). No statistically significant difference was found in VEGF expression between lymphoma subtypes and between low grade and high grade groups $(\mathrm{P}>0.05)$. VEGF-positive reactive cells displayed weak cytoplasmic staining and consisted of macrophages, variable amounts of lymphocytes and endothelial cells.

\section{DISCUSSION}

Non-Hodgkin lymphoma (NHL) is a heterogeneous group of lymphoproliferative malignancies with differing patterns 
Table I: VEGF expression profile of patients was shown according to the histological subtypes of B-cell non-Hodgkin's lymphoma

\begin{tabular}{|l|c|c|c|c|}
\hline \multirow{2}{*}{$\begin{array}{l}\text { World Health Organization } \\
\text { classification }\end{array}$} & \multirow{2}{*}{ No. of patients } & \multicolumn{3}{|c|}{ VEGF Expression (No. of patients) } \\
\cline { 3 - 5 } & & Negative & Weak expression & Strong expression \\
\hline Follicular lymphoma & 7 & 2 & 1 & 4 \\
\hline Small lymphocytic lymphoma & 6 & 1 & 1 & 4 \\
\hline Diffuse large B-cell lymphoma & 29 & 10 & 4 & 15 \\
\hline Burkitt's lymphoma & 9 & 3 & 4 & 2 \\
\hline Total & 53 & 17 & 10 & 26 \\
\hline
\end{tabular}
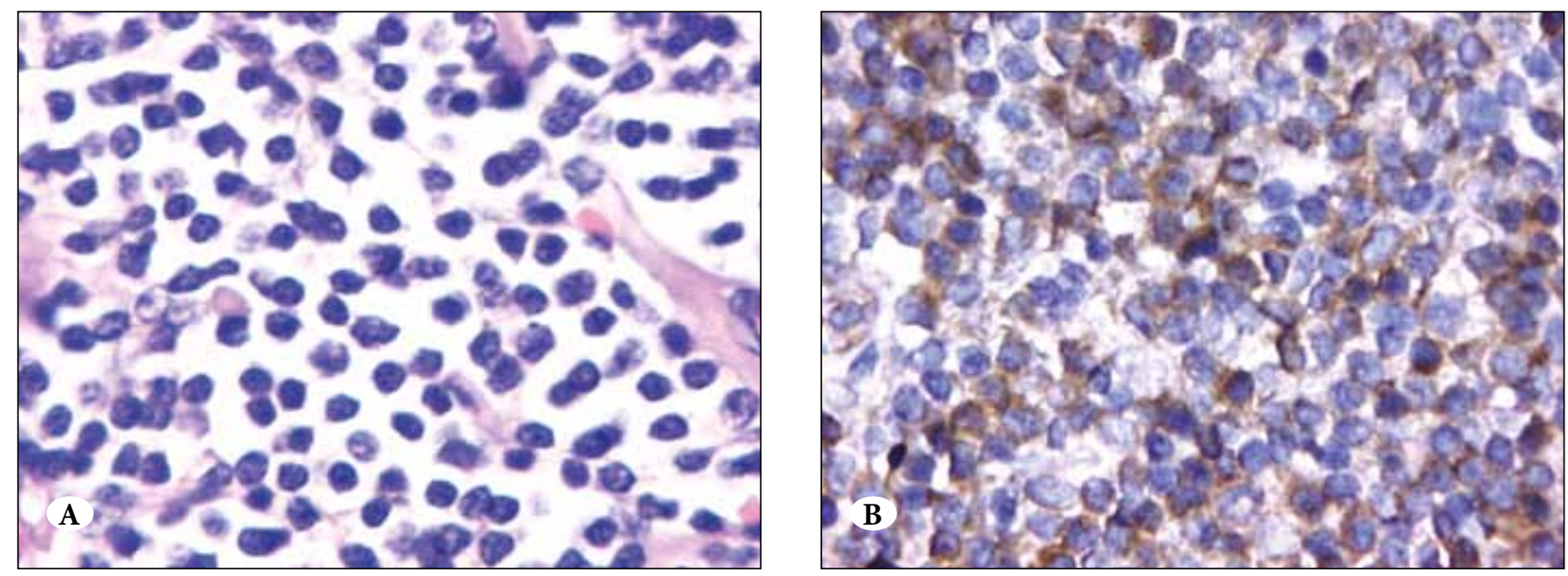

Figure 1: Small lymphocytic lymphoma (A) H\&E (x400), and (B) strong VEGF staining (x400).
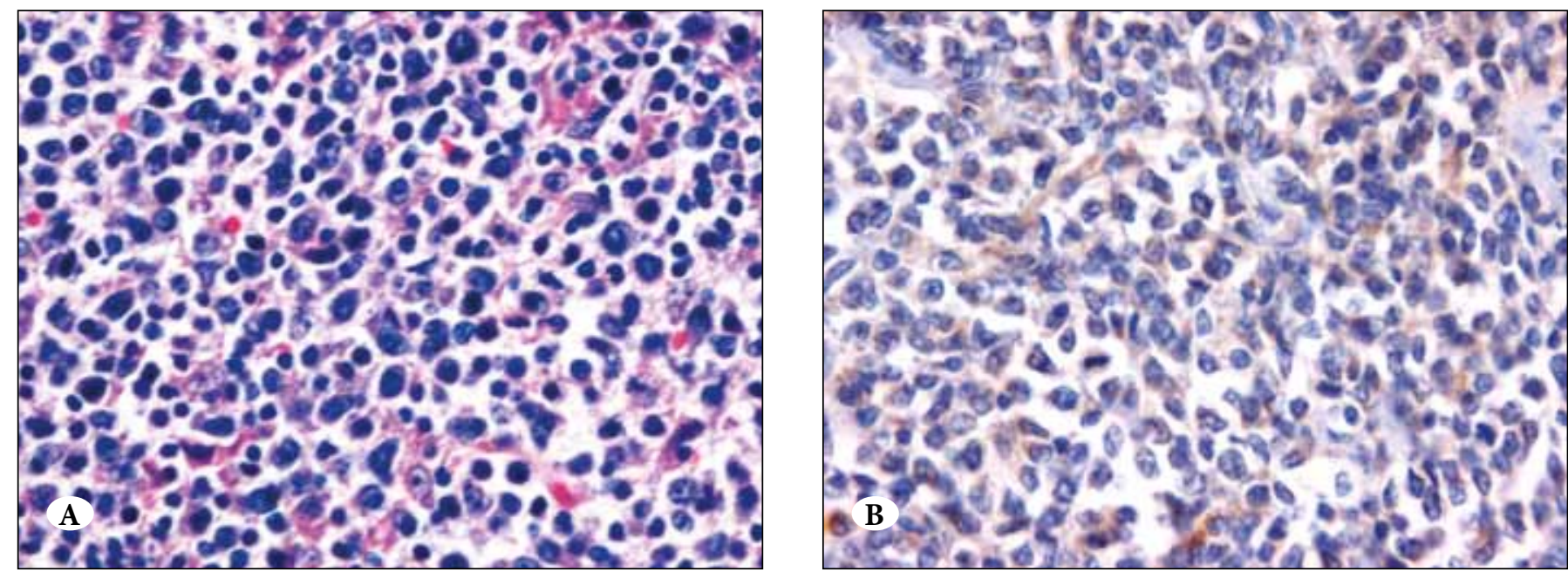

Figure 2: Diffuse large B-cell lymphoma (A) H\&E (x200), and (B) strong VEGF staining (x200)

of behavior and response to treatment. Although many patients with NHL are cured by therapy, some are not cured and ultimately die of their disease. The heterogeneity of NHL is likely to be the clinical reflection of several intrinsic biological characteristics and histopathological features of the tumor (3). The prognostic and predictive value of angiogenic factors in lymphomas is still controversial due to the heterogeneity of diseases, different classification systems and methods for analysis. In this regard, we investigated an important angiogenic factor, VEGF, by examining the immunohistochemical expression profile in subgroups of NHL. We studied on a restricted group which included 
FL, SLL, DLBCL and BL. Some cases such as mantle cell, marginal zone or $\mathrm{T}$ cell rich B cell lymphoma were excluded from the study because of the relatively small numbers.

Growth factors that stimulate angiogenesis can be divided into direct and indirect angiogenic molecules. The origin of these molecules are supposed to be tumor cells or stromal cells (6-8). VEGF is a direct angiogenic molecule secreted by tumor cells, peripheral blood cells, B and T lymphocytes, and granulocytes (9-12). VEGF mRNA transcription is induced by hypoxia and a variety of growth signals and cytokines. VEGF is a $40-45 \mathrm{kDa}$ homodimer protein that promotes blood vessel growth by stimulating endothelial cells to migrate and proliferate. VEGF is also known as vascular permeability factor because it acts on endothelial cells to regulate permeability. VEGF-mediated angiogenesis requires tyrosine kinase receptors (13).

Lymphoma growth and progression appear to be promoted by two mechanisms of VEGF signaling. The first mechanism is autocrine stimulation of tumor cells via expression of VEGF and VEGF receptors (VEGFR) by lymphoma cells. Dias et al. found that certain leukemias not only produce VEGF but also express functional VEGFR-2 in vivo and in vitro, resulting in the generation of an autocrine loop that may support leukemic cell survival and proliferation (14). The second mechanism is paracrine influences of the other growth factors after stimulation of VEGF (15).

VEGF could be the major angiogenic factor in tumorigenesis and tumor progression of NHL. Although several studies contest a direct correlation between circulating levels of VEGF in the serum and intratumoral neovascularization $(16,17)$, an increased level of serum VEGF has been reported more frequently in high-grade NHL (18-20). Moreover, Salven et al. found that serum concentration of VEGF has an independent prognostic influence on survival in NHL and they proposed to use this measurement to identify a subgroup of NHL patients with particularly poor outcome (19). Besides, Foss et al. showed that VEGF was minimally expressed or absent in low-grade B-cell lymphomas (7). In the present study, we evaluated the VEGF expression in neoplastic lymphocytes by immunohistochemistry. Even though the study cohort had restriction of the subtypes of B-NHL; we found no difference between the low and high grade B-NHL groups. VEGF has also been implicated in the overall disease course of NHL. VEGF levels were found to be significantly lower in patients in complete remission compared with those with progressive disease (20). Therefore, it could be concluded that VEGF expression in lymphomas parallels their proliferative activity. Recently, Jorgensen et al. showed that diffuse intratumoral VEGF staining correlated with shorter overall survival in FL (21). Ganjoo et al. reported high VEGF expression to have a negative impact on outcome in 97 cases of DLBCL (22). However, we were not able to speculate reliably on the results regarding this subject in this study, due to the lack of clinical follow-up data and subtype-specific analysis.

Some authors also report a positive correlation between neovascularization and tumor grade according to several lymphoma classification systems. Angiogenesis was compared between patients with NHL and benign lymphadenopathy in one study. Neovascularization was significantly higher in nodal lymphomas, particularly in those that were highly proliferative, than in reactive lymph nodes. It was concluded that angiogenesis also contributes to tumorigenesis and tumor progression of NHL (23). Angiogenic factors are therefore presumed to play an important role in higher grades of NHL. However, we did not examine neovascularization in this study.

Angiogenesis in many human tumors is linked to the expression of VEGF and the inhibition of VEGF has been shown to suppress tumor growth (24). From this data, lymphoma cells expressing stronger VEGF staining may be good targets for antiangiogenic therapy. On the other hand, it is unlikely that only one angiogenic factor contributes to angiogenesis in a specific tumor considering the interaction between positive and negative angiogenic factors. A dominant angiogenic factor may still induce angiogenesis in vivo in any tumor (25). The interplay between lymphoma cells and tumor vessels is complex (26). It is therefore difficult to determine which angiogenic factor could lead to angiogenesis and tumor progression in NHL.

Through immunohistochemical studies one can directly investigate whether tumor cells produce angiogenic factors. The VEGF immunohistochemistry is reflective of effective local VEGF signaling. In this study, we examined VEGF immunohistochemically and showed that most lymphoma cells expressed VEGF. However, there was no statistical significance in VEGF expression between histological types and low or high grade B-NHL. This could be related to the technique that only assessed the protein expression. In this regard, the effect of tyrosine kinase receptors was not considered. Cellular expression of VEGF seems common in NHL in the literature (27); however, VEGF receptor coexpression appears limited according to the studies which also evaluated the receptor status (28).

In conclusion, many studies emphasized the essential role of angiogenesis and the regulators of neoangiogenesis such as VEGF/VEGFR-related pathways in the development and 
progression of lymphomas. However, the populations used in these studies were heterogeneous regarding lymphoma subtype. This means that the results of these studies do not have to apply for each lymphoma subtype. In the present study, we showed the expression of VEGF in many lymphoma patients by immunohistochemistry. However, we were not able to show any difference between low and high grade B-NHL. Significant results between the low and high grade lymphomas could be obtained by increasing the number of patients in the studied groups, constituting more specific lymphoma subgroups and using highly sensitive techniques to assess angiogenesis pathways.

\section{REFERENCES}

1. Jain RK: Tumor angiogenesis and accessibility: role of vascular endothelial growth factor. Semin Oncol 2002, 29:3-9

2. Ferrara N: Role of vascular endothelial growth factor in physiologic and pathologic angiogenesis: therapeutic implications. Semin Oncol 2002, 29:10-14

3. Swerdlow SH, Campo E, Harris NL, Jaffe ES, Pileri SA, Stein H, Thiele J, Vardiman JW: World Health Organization (WHO) Classification of Tumours, Pathology and Genetics, Tumours of Haematopoietic and Lymphoid Tissues. 4th ed., Lyon, IARC Press, 2008

4. Ito H, Oshita F, Kameda Y, Suzuki R, Ikehara M, Arai H, Mitsuda A, Saito H, Yamada K, Noda K, Nakayama H: Expression of vascular endothelial growth factor and basic fibroblast growth factor in small adenocarcinomas. Oncol Rep 2002, 9:119-123

5. Giatromanolaki A, Sivridis E, Kouskoukis C, Gatter KC, Harris AL, Koukourakis MI: Hypoxia-inducible factors 1alpha and 2 alpha are related to vascular endothelial growth factor expression and a poorer prognosis in nodular malignant melanomas of the skin. Melanoma Res 2003,13:493-501

6. Aguayo A, Kantarjian H, Manshouri T, Gidel C, Estey E, Thomas D, Koller C, Estrov Z, O'Brien S, Keating M, Freireich E, Albitar M: Angiogenesis in acute and chronic leukemias and myelodysplastic syndromes. Blood 2000, 96:2240-2245

7. Foss HD, Araujo I, Demel G, Klotzbach H, Hummel M, Stein H: Expression of vascular endothelial growth factor in lymphomas and Castleman's disease. J Pathol 1997, 183:44-50

8. Bellamy WT, Richter L, Frutiger Y, Grogan TM: Expression of vascular endothelial growth factor and its receptors in hematopoietic malignancies. Cancer Res 1999, 59:728-733

9. Salven P, Orpana A, Joensuu H: Leukocytes and platelets of patients with cancer contain high levels of vascular endothelial growth factor. Clin Cancer Res 1999, 5:487-491

10. Wartiovaara U, Salven P, Mikkola H, Lassila R, Kaukonen J, Joukov V, Orpana A, Ristimäki A, Heikinheimo M, Joensuu $\mathrm{H}$, Alitalo K, Palotie A: Peripheral blood platelets express VEGF-C and VEGF which are released during platelet activation. Thromb Haemost 1998, 80:171-175
11. Freeman MR, Schneck FX, Gagnon ML, Corless C, Soker S, Niknejad K, Peoples GE, Klagsbrun M: Peripheral blood T lymphocytes and lymphocytes infiltrating human cancers express vascular endothelial growth factor: a potential role for $\mathrm{T}$ cells in angiogenesis. Cancer Res 1995, 55:4140-4145

12. Heslan JM, Branellec A, Laurent J, Lagrue G: The vascular permeability factor is a T lymphocyte product. Nephron 1986, 42:187-188

13. McMahon G: VEGF receptor signaling in tumor angiogenesis. Oncologist 2000, 5:3-10

14. Dias S, Hattori K, Zhu Z, Heissig B, Choy M, Lane W, Wu Y, Chadburn A, Hyjek E, Gill M, Hicklin DJ, Witte L, Moore MA, Rafii S: Autocrine stimulation of VEGFR-2 activates human leukemic cell growth and migration. J Clin Invest 2000, 106: 511-521

15. Ruan J, Hajjar K, Rafii S, Leonard JP: Angiogenesis and antiangiogenic therapy in non-Hodgkin's lymphoma. Ann Oncol 2009, 20:413-424

16. Byrne GJ, Bundred NJ: Surrogate markers of tumoral angiogenesis. Int J Biol Markers 2000, 15:334-339

17. Adams J, Carder PJ, Downey S, Forbes MA, MacLennan K, Allgar V, Kaufman S, Hallam S, Bicknell R, Walker JJ, Cairnduff F, Selby PJ, Perren TJ, Lansdown M, Banks RE: Vascular endothelial growth factor (VEGF) in breast cancer: comparison of plasma, serum, and tissue VEGF and microvessel density and effects of tamoxifen. Cancer Res 2000, 60:2898-2905

18. Salven P, Teerenhovi L, Joensuu H: A high pretreatment serum vascular endothelial growth factor concentration is associated with poor outcome in non-Hodgkin's lymphoma. Blood 1997, 90:3167-3172

19. Salven P, Orpana A, Teerenhovi L, Joensuu H: Simultaneous elevation in the serum concentrations of the angiogenic growth factors VEGF and bFGF is an independent predictor of poor prognosis in non-Hodgkin lymphoma: a single-institution study of 200 patients. Blood 2000, 96:3712-3718

20. Bertolini F, Paolucci M, Peccatori F, Cinieri S, Agazzi A, Ferrucci PF, Cocorocchio E, Goldhirsch A, Martinelli G: Angiogenic growth factors and endostatin in non-Hodgkin's lymphoma. Br J Haematol 1999,106:504-509

21. Jørgensen JM, Sørensen FB, Bendix K, Nielsen JL, Funder A, Karkkainen MJ, Tainola T, Sørensen AB, Pedersen FS, D'Amore F: Expression level, tissue distribution pattern, and prognostic impact of vascular endothelial growth mfactors VEGF and VEGF-C and their receptors Flt-1, KDR, and Flt-4 in different msubtypes of non-Hodgkin lymphomas. Leuk Lymphoma 2009, 50:1647-1660

22. Ganjoo KN, Moore AM, Orazi A, Sen JA, Johnson CS, An CS: The importance of angiogenesis markers in the outcome of patients with diffuse large B cell lymphoma: a retrospective study of 97 patients. J Cancer Res Clin Oncol 2008, 134:381-387

23. Ribatti D, Vacca A, Nico B, Fanelli M, Roncali L, Dammacco F: Angiogenesis spectrum in the stroma of B-cell non-Hodgkin's lymphomas. An immunohistochemical and ultrastructural study. Eur J Haematol 1996, 56:45-53 
24. Kim KJ, Li B, Winer J, Armanini M, Gillett N, Phillips HS, Ferrara $N$ : Inhibition of vascular endothelial growth factorinduced angiogenesis suppresses tumour growth in vivo. Nature 1993, 362:841-844

25. Carmeliet P, Jain RK: Angiogenesis in cancer and other diseases. Nature 2000, 407:249-257

26. Passalidou E, Stewart M, Trivella M, Steers G, Pillai G, Dogan A, Leigh I, Hatton C, Harris A, Gatter K, Pezzella F: Vascular patterns in reactive lymphoid tissue and in non-Hodgkin's lymphoma. Br J Cancer 2003, 88:553-559
27. Hazar B, Paydas S, Zorludemir S, Sahin B, Tuncer I: Prognostic significance of microvessel density and vascular endothelial growth factor (VEGF) expression in non-Hodgkin's lymphoma. Leuk Lymphoma 2003,44:2089-2093

28. Aguayo A, Estey E, Kantarjian H, Mansouri T, Gidel C, Keating M, Giles F, Estrov Z, Barlogie B, Albitar M: Cellular vascular endothelial growth factor is a predictor of outcome in patients with acute myeloid leukemia. Blood 1999, 94:3717-3721 